\title{
TAK TO SIE WSZYSTKO ZACZĘŁO. GARŚĆ WSPOMNIEŃ Z MOJEJ WSPÓŁPRACY Z PROF. F. GRONOWSKIM Z OKAZJI 90. ROCZNICY URODZIN PROFESORA
}

\author{
Ignacy H. Chrzanowski \\ Wyższa Szkoła Biznesu w Dąbrowie Górniczej
}

Do mojego pierwszego spotkania z Profesorem doszło w maju 1968 roku. Tego dnia, którego dokładnej daty już nie pamiętam, wsiadłem wraz z kolegami z roku - Krzysztofem Luksem i Andrzejem Rucińskim do porannego „ekspresu”, kursującego miedzy Trójmiastem a Szczecinem, aby stawić się na Wydziale Inżynieryjno-Ekonomicznym Transportu Politechniki Szczecińskiej na rozmowę z Prof. Gronowskim, kierującym wówczas Katedrą Transportu Morskiego i Śródlądowego na tym Wydziale. Ani nazwa wydziału ani katedry niewiele nam mówiła, pomijając kilka krążących wówczas po sopockiej WSE plotek, że w Szczecinie pracuje niejaki docent Koselnik, zajadły oponent „naszego” prof. Kasprowicza, jedynego, według panującej na WSE opinii, autorytetu w sprawach portowych. Kością niezgody pomiędzy obydwu profesorami był spór o to czy port morski jest węzłem, czy też ogniwem transportu. Gdyby ktoś zadał mi to pytanie dzisiaj odpowiedziałbym, chyba bez chwili wahania, ze jest jednym i drugim, nie mówiąc już o kilku innych funkcjach gospodarczych i pozagospodarczych portu morskiego. Wtedy jednak niewielu z nas, studentów ostatniego roku studiów na WSE, ośmieliłoby się wypowiadać w tej kwestii, uznając ją za temat zarezerwowany dla wybitnych specjalistów w dziedzinie portów morskich.

$\mathrm{Z}$ prof. Kasprowiczem miałem tylko jedno bezpośrednie spotkanie w ciągu pięciu lat studiów, gdyż wykładów z ekonomiki transportu wysłuchiwałem podczas zajęć prowadzonych przez ówczesnego dr Andrzeja Piskozuba. To on zresztą zasugerował mi, za pośrednictwem jednego z kolegów, wyjazd do Szczecina celem odbycia rozmowy z kierownikiem wspomnianej wyżej katedry w sprawie podjęcia stażu asystenckiego na Politechnice Szczecińskiej. Warunkiem było to, że kandydat na to stanowisko, nie mógł specjalizować się w transporcie kolejowym. Jako zapamiętały student prawa morskiego warunek powyższy spełniałam par excellence.

Wracając do prof. Kasprowicza, to jedyne z Nim spotkanie omal nie zakończyło się dla mnie katastrofą, której wyrazem jest przedziurawiona w moim indeksie strona, gdzie profesor wyskrobał mizerną trójkę z minusem, będącą dowodem jego zdegustowania studentem niepotrafiącym wymienić w niemieckim oryginale pięciu „praw transportowych” E. Saxa. Na moją nieśmiałą uwagę, że uczę się języka angielskiego, a z niemieckim nie mam wiele wspólnego, 
profesor tylko się żachnął i pokazał mi drzwi. Nawiasem mówiąc miałem pecha, gdyż egzaminatorem miał być dr Piskozub, zaś profesor Kasprowicz, który chyba się trochę tego poranka nudził, postanowił wyręczyć swojego adiunkta. Po prostu wyglądnął z gabinetu, pod którym właśnie stałem czytając jakieś ogłoszenia, a zobaczywszy mnie zapytał czy czekam na egzamin. Nie mogłem zaprzeczyć i w taki oto sposób znalazłem się przed groźnym obliczem prof. Kasprowicza. Dobrze, że na tym sprawa się zakończyła, bo gdyby do incydentu doszło dzisiaj i gdybym odpowiedział, że „prawa transportowe” Saxa to zupełne nieporozumienie, miałbym się z pyszna.

Wróćmy jednak do naszej podroży, która rozpoczęła się o świcie owego majowego dnia. Po usadowieniu się w wagonie klasy II ekspresu, który tego dnia był stosunkowo mało wypełniony, próbowałem się trochę zdrzemnąć. Niestety ożywiona dyskusja dwóch adeptów walk powietrznych trochę mi w tym przeszkadzała. Godzi się nadmienić, że Andrzej Ruciński to pilot aeroklubu w Grudziądzu. Krzysztof Luks to inna zupełnie karta. Do pilotażu się nie garnął, ale był znany jako miłośnik wojskowości w jej każdej niemal postaci. Jego największym wyczynem, o którym krążyły legendy po całym Sopocie, a nawet poza tym miastem, było to, ze na obóz wojskowy po IV roku studiów pojechał na własną odpowiedzialność, gdyż komisja lekarska obawiała się, ze może nie podołać wymogom życia koszarowego i poligonowego. Wytrzymał, a jego miłość do wojska stała się jeszcze mocniejsza.

Nie będę szerzej opisywał tu incydentu marszu na azymut $\mathrm{z}$ udziałem Krzysztofa jako dowódcy drużyny, w kierunku odwrotnym od wskazanego w rozkazie przełożonego, czy też głębokiego niezadowolenia szeregowego Wicia P., który się denerwował, że „nie tylko musiał ciągnąc ten cholerny ckm ale jeszcze i Luksa razem z nim”. Kłócąc się bez przerwy o to, kto się obija w czasie marszu przez las, panowie ci zgubili zamek do ckm-u. Co się działo potem to już osobna historia.

Otóż Andrzej i Krzysztof, gdzieś już od Wejherowa, byli całkowicie pochłonięci „walką” powietrzną, tzw. dog fight nad Kanałem La Manche. Nie pamiętam już, który z nich "pilotował” Me109, a który Spitefire’a, ale to nie miało znaczenia gdyż co chwila wybuchała zażarta dyskusja, żeby nie powiedzieć kłótnia, czy lecący ze słońcem Messerschmidt wpakował długą serie w cockpit Spifire’a czy też ten ostatni wykonał przewrotkę na plecy i ze środkowego karabinu maszynowego kilkoma krótkimi seriami rozpruł brzuch Me109 i posłał go w wody Kanału la Manche. „Walka” tych dwóch godnych siebie asów lotnictwa myśliwskiego (nie pamiętam już czy przypadkiem „pilot” Me109 to nie był słynny Adolf Galland, ten sam, który miał odwagę zakpić sobie z Reichsmarschala Goeringa) jeszcze trwała, kiedy ujrzeliśmy majestatyczne budynki stojące wzdłuż Wałów Chrobrego. Wtedy jeszcze nie wiedziałem, że tak się to miejsce nazywało. Po krótkiej jeździe taksówką znaleźliśmy się na ul. Mickiewicza 66. Portier poinformował nas, że Katedra znajdowała się na drugim piętrze. Zanim zdecydowaliśmy się zapukać, obejrzeliśmy tabliczki z nazwiskami pracowników. Figurowały na nich nazwiska aż trzech docentów, co w czasach gdy nawet doktorów w większości katedr jakie znaliśmy było jak na lekarstwo, stanowiło pewne zaskoczenie. Poza trzema docentami w Katedrze nie było nikogo innego, nawet asystenta.

I oto stanęliśmy przed obliczem dzisiejszego Jubilata. Wydał mi się młodszy niż to sobie wyobrażałem. Zapytał, który z nas to I. Chrzanowski (obydwaj moi współtowarzysze udawali się do Szczecina w sposób nieco zaimprowizowany, gdyż ustalenia z dr Piskozubem dotyczyły na 
razie tylko mojej skromnej osoby) i poprosił nas o zejście do dziekanatu dokąd wkrótce przybył prof. J. Rutkowski - ówczesny dziekan WIET. Rozmowa dotyczyła naszych studiów, terminów ich ukończenia i tematyki prac magisterskich. Profesor Gronowski stwierdził, że może przyjąć dwóch kandydatów. Andrzej Ruciński, który nie interesował się transportem morskim (wiadomo pilot!) przyjął propozycję dziekana Rutkowskiego zatrudnienia w Katedrze Ekonomii Politycznej. Nie zagrzał zresztą w niej miejsca, gdyż wrócił do Sopotu pod opiekuńcze skrzydła, chyba już wtedy docenta, A. Piskozuba. Pozostał tam do dzisiaj.

Co do nas obu, tzn. Krzysztofa Luksa i mnie, Profesor Gronowski zadecydował na miejscu, że każdy z nas będzie się zajmował odrębną problematyka - Krzysztof portami, ja zaś żeglugą. I tak było przez następnych 10 lat aż do mojego wyjazdu ze Szczecina i pożegnania z Politechniką Szczecińską, do której już nigdy potem nie miałem powrócić.

Dzisiaj z całą wyrazistością widzę, jak sztuczny był to podział, ale w owym czasie była to iście salomonowa decyzja naszego Szefa. Każdy miał swoją działkę. Krzysztof zazdrośnie pilnował swojej i każda moja próba, nawet najmniejsza, wejścia choćby w ograniczony sposób w problematykę portową wywoływała Jego natychmiastowy sprzeciw.

Mimo tej wyraźnej „grubej kreski na piasku” istniała między nami rywalizacja, wychodząca także poza sprawy zawodowe. Na mój zakup samochodu osobowego marki „Syrena”, Krzysztof zareagował nabyciem „półtoralitrowego”, jak to sam określał, Fiata 125p.

Wrócę na chwilę do tej pamiętnej podróży do Szczecina. Otóż przywiodła mnie do tego miasta chyba ciekawość, gdyż do spotkania z dr Piskozubem, który przedstawił mi propozycje pracy na Politechnice Szczecińskiej, w przeciwieństwie do moich dwóch kolegów, którzy byli już do tego niemalże konsekrowani, nie myślałem o karierze naukowej. Miałem już nawet ofertę pracy w Komisariacie Awaryjnym PIHZ w Gdyni. Nie bez znaczenia było również to, że opuszczając Trójmiasto musiałbym się rozstać z moją przyszłą małżonką, która mi towarzyszy po dzisiaj. Innym powodem przyjęcia „opcji szczecińskiej” było to, że niedoszłymi absolwentami uczelni sopockiej, którzy nie mieli wówczas stypendiów, ani jakichś umów przedwstępnych, czy czegoś w tym rodzaju,, interesowały się rożnego rodzaju służby. Mnie konkretnie proponowano pracę w KWMO w Koszalinie. Nie skorzystałem z tej oferty, chociaż była ona materialnie nieporównanie korzystniejsza niż asystentura.

I tak biegły miesiące i lata. W połowie lat 70. uzyskaliśmy stopnie doktora habilitowanego. Nie pamiętam w jakim odstępie, ale to już nie miało większego znaczenia. Trzeba podkreślić z naciskiem, ze Jubilat jako nasz ówczesny szef popierał nasze „wyczyny”, jak np. doktorat w wieku 25 lat czy habilitacja przed trzydziestką. Pod tym względem Krzysztof miał nade mną niejako „naturalna” przewagę, gdyż jest ode mnie młodszy niemal o cały rok.

Moje próby podjęcia pracy w ONZ jeszcze w latach 1975-1976 zakończyły się niepowodzeniem i zdecydowaną odmową władz PRL, a także naganą. Udało mi się natomiast wyjechać do pracy w ramach „Polservice” w 1978 roku. Duża w tym zasługa dzisiejszego Dostojnego Jubilata, który nie sprzeciwił się moim staraniom, rozumiejąc, że jest to jedyny sposób zarobienia trochę grosza, głównie z powodu absurdalnego w owym czasie przelicznika dolara na złotówki. I za to chcę Mu złożyć w tym miejscu serdeczne podziękowania.

Nie dane mi jednak było skorzystać z tych z takim trudem zgromadzonych oszczędności. W obecnych warunkach nie wystarczyłyby one zresztą nawet na zakup skromnego mieszkania lub jeszcze skromniejszego samochodu. Po czterech latach pracy dla „Polservice” czekały mnie 
brzemienne w skutkach wydarzenia. Kiedy w końcu uzyskałem stanowisko w ONZ, mimo wystąpienia do władz PRL z prośbą o akceptację mojego projektu, który miał trwać siedem lat, władze te wystąpiły do Narodów Zjednoczonych z żądaniem odwołania mnie ze stanowiska już po roku pracy. Z dnia na dzień stałem się persona non grata, chociaż mój ówczesny przełożony Ambasador ONZ przy Rządzie Republiki Kości Słoniowej - wynegocjował dla mnie jeszcze jeden rok pracy nad projektem. Wtedy zrozumiałem, że powrót do kraju nie obyłby się bez surowych sankcji, tym bardziej, że był to okres stanu wojennego. W tej sytuacji wystąpiliśmy z żona o pozwolenie osiedlenia się w Kanadzie. Reszta jest już historią.

Szczecin, czerwiec 2016 rok 